\title{
Evaluation of the wound healing potential of an ointement formulated with Chromoleana odorata (L.) R. M. King \& H. Rob. (Asteraceae)
}

Ngene Jean Pierre ${ }^{1}$, Ladoh-Yemeda Christelle Flora ${ }^{1}{ }^{2 *}$, Ngoule Charles Christian ${ }^{1}$, Yingyang Jacques ${ }^{1}$, Ekorong Dang Estelle $^{1}$, Etamè-Loé Gisèle ${ }^{1}$

${ }^{1}$ Pharmaceutical Science Laboratory, Faculty of Medicine and Pharmaceutical Science P.O. BOX 2701, University of Douala, Cameroon

${ }^{2}$ Laboratory of Biology and Physiology of Plant Organisms, Faculty of Science P.O. BOX 24157, University of Douala, Cameroon

DOI: $\underline{10.36348 / \text { sijtcm.2020.v03i10.001 }}$

| Received: 02.11.2020 | Accepted: 11.11.2020 | Published: 14.11 .2020

*Corresponding author: Ladoh-Yemeda Christelle Flora

\section{Abstract}

Chromoleana odorata is an invasive plant traditionally used for the treatment of many diseases in Cameroon in both humans and animals. The objective of this study was to evaluate the healing potential of a watery ointment extract from the $C$. odorata leaves on a model of excision wound in Wistar strain rat. Phytochemical screening was evaluated using standard procedures. A 5\% ointment (CO-5\%) aqeuous extract with simple excipients (Vaseline and water) was formulated and evaluated for wound healing testing. Chemical screening showed the presence of alkaloids, flavonoids, tannins, saponins, terpenoids and anthraquinones in the extract. The application of the ointment alone to the wounds caused a complete healing in rats on the 16th day. Under similar conditions, the reference ointment allowed complete healing after 21 days. These results confirm the therapeutic efficacy of this plant in traditional wound care.

Keywords: Chromoleana odorata, Wound healing, Ointment, Traditional Medicine.

Copyright (C) 2020 The Author(s): This is an open-access article distributed under the terms of the Creative Commons Attribution 4.0 International License (CC BY-NC 4.0) which permits unrestricted use, distribution, and reproduction in any medium for non-commercial use provided the original author and source are credited.

\section{INTRODUCTION}

Traditional medicine is defined as the sum of knowledge, skills and practices that rationally or unintentionally are based on culture-specific theories, beliefs and experiences that are used to keep human beings healthy and to prevent, diagnose, treat and heal physical and mental patients [1]. This medicine has always been important in Africa, where nearly $80 \%$ of the population continues to use traditional medicines for primary health care [2]. The practice of herbal medicine based on scientific advances seeks active extracts of plants, standardizes them, and thus leads to the production of phytomedics or even to improved traditional medicines (MTA). The exploration of plants used in traditional medicine is a priority strategy for the development of MTAs [3]. Chromoleana odorata is an invasive weed plant widespread in Cameroon; it would occupy almost all parts of Africa. Its invasion has caused a worrying ecological upheaval, however studies have shown that this plant has significant ecological and agronomic assets. $C$. odorata is a cover plant that intervenes in the control of erosion thus constituting an effective protection of the soil. It also contributes to the improvement of soil fertility through significant organic matter production $[4,5]$. In traditional medicine, this plant is used to accelerate wound healing and stop bleeding in many tropical countries [6]. It is also used to treat incurable wounds in diabetics as well as to treat infections of microbial origin [7]. Extract from C. odorata is used in the treatment of HIV/AIDS-related dermatoses [8]. The purpose of this study is to assess the healing potential of an ointment extract from $\mathrm{C}$. odorata leaves on an excision wound model in Wistar rats.

\section{MATERIALS AND METHODS \\ Plant material}

Fresh leaves from Chromoleana odorata were collected from Akonolinga town (Central region, Cameroon). The identification was done at the Laboratory of Biology and Physiology of Plant Organisms and was confirmed by the National Herbarium of Cameroon compared to a sample kept under L9520HNC number.

\section{Extraction}

The leaves were washed with distilled water and dried at room temperature away from the light then powdered by grinding. The powder was macerated in distilled water (1:5 weight/volume) at $37^{\circ} \mathrm{C}$ for 24 hours, the macerate was filtered and the mark was macerated again for 24 hours. The complete process was repeated to ensure complete extraction of 
metabolites. The resulting filters were mixed and dried in the oven for 36 hours at $45^{\circ} \mathrm{C}$ to obtain a dry aqueous extract.

\section{Phytochemical screening of water extract}

The qualitative phytochemical study revealed the secondary metabolites present in Chromoleana odorata extract. It was carried out using the standard protocols $[9,10]$. Each of the tests was qualitatively expressed as absence (-) or presence $(+)$.

\section{Formulation of ointment}

The formulation of ointment based on Chromoleana odorata extract has been prepared at $5 \%$ (CO-5 \%) with Vaseline as its main excipient because of its stability and compatibility with most active ingredients. The extract of C. odorata was crushed with a pestle. Pure Vaseline was gradually added in small portions, grinding slightly until the mixture is homogenized. A 5\% ointment was obtained (Qsp $50 \mathrm{~g}$ $5 \mathrm{~g}$ for losses) (Table 1). Pharmacotechnical tests were then carried out to determine the adequacy of the tested formula.

Table-1: Ointment Composition

\begin{tabular}{|l|l|l|}
\hline & Placebo (Vaseline) & $\begin{array}{l}\text { Extract } \\
\text { (CO-5\%) }\end{array}$ \\
\hline Aqueuse extract de Chromoleana odorata (g) & 0 & 2,75 \\
\hline Vaseline (g) & 55 & 52,25 \\
\hline Total & 55 & 55 \\
\hline
\end{tabular}

\section{Wound healing test}

\section{Induction of wounds}

Healing potential was assessed in an experimental wound model in rats [11]. 20 female Wistar rats aged 8 to 12 weeks weighing between 180 and $200 \mathrm{~g}$ were divided into 4 groups of 5 animals each and place in 4 cages labeled (1-4) : group 1 (untreated animals), group 2 (pure pharmaceutical Vaseline), group 3 (Biafine healing medicine), group 4 and (treated with extract). Animals were anesthetized with a $100 \mathrm{ml}$ solution of ketamine $(13.22 \mathrm{ml})$, Acepromazine $(2.11 \mathrm{ml})$ and water $(84,656 \mathrm{ml})$ by intra-peritoneal injection $(1 \mathrm{ml} / 100 \mathrm{~g})$. The dorsal flank of the rats was shaved on $1.5 \mathrm{~cm} 2$ and cleaned with yellow Betadine. Wounds $0.2 \mathrm{~cm}$ deep were induced on decontaminated surfaces with knife blades, pliers and surgical scissors.

\section{Evaluation of healing activity of water extract from Chromoleana odorata leaves}

Healing activity was assessed by a macroscopic technique (simple clinical observation) by measuring the lengths and widths of excision wounds of each group every 4 days for 21 days. The narrowing of the wound was assessed by measuring its surface.

\section{STATISTICAL ANALYSIS}

The results of the different experiments are expressed in mean \pm standard deviations. The means were analyzed using variance analysis (ANOVA). A $\mathrm{p}<0.05$ value was considered significant.

\section{RESULTS}

\section{Qualitative phytochemical characterization}

The phytochemical screening of aqueous extract of the Chromoleana odorata leaves revealed the presence of alkaloids, anthocyanin, anthraquinone, flavonoids, polyphenols, saponins, steroids, tannins and triterpenes (Table 2).
Table-2: Phytochemical profile of Chromoleana odorata extract

\begin{tabular}{|l|l|}
\hline Secondary metabolites & Extract \\
\hline Alkaloid & + \\
\hline Anthocyanin & + \\
\hline Anthraquinone & + \\
\hline Flavonoids & + \\
\hline Phenols & - \\
\hline Polyphenols & + \\
\hline Saponins & + \\
\hline Steroids & + \\
\hline Tannins & + \\
\hline Triterpenes & + \\
\hline
\end{tabular}

\section{Evaluation of wound healing}

Effect of treatments on the healing process

Treatment resulted in a complete healing of the wounds. Cleaning the cages every day favoured the absence of infection, the wounds were not fragrant. The observational results showed that the group treated with Chromoleana odorata extract does not show crust or inflammation on the 21 st day of treatment (Table 3). In addition, surfaces treated with the extract were more hydrated.

Table-3: Wound healing activity of different groups on the 21st day of treatment

\begin{tabular}{|l|l|l|}
\hline Groups & Presence of crusts & Inflammation \\
\hline $\mathbf{1}$ & Yes & Yes \\
\hline $\mathbf{2}$ & Light crust & Yes \\
\hline $\mathbf{3}$ & Yes & Slight \\
\hline $\mathbf{4}$ & No & No \\
\hline
\end{tabular}

\section{Evolution of wounds}

The group 1 without any treatment did not heal after 20 days of observation. Animals showed thick crusts from the fourth day of observation. The average surface of unhealed wounds after 20 days was 90.05 $\mathrm{mm} 2$. Group 2 treated with Vaseline did not heal completely after 20 days of observation, crusts were 
light. The average area of unhealed wounds after 20 days was $78.26 \mathrm{~mm} 2$. Group 3 treated with Biafine had mild crusts from the fourth day on. Two animals of the group healed after 16 days and the other three healed after 20 days of observation. Group 4 treated with $5 \%$ ointment Chromoleana odorata did not have a crust during healing. Four animals healed after 16 days and one after 20 days of observation. The results were statistical between each group.

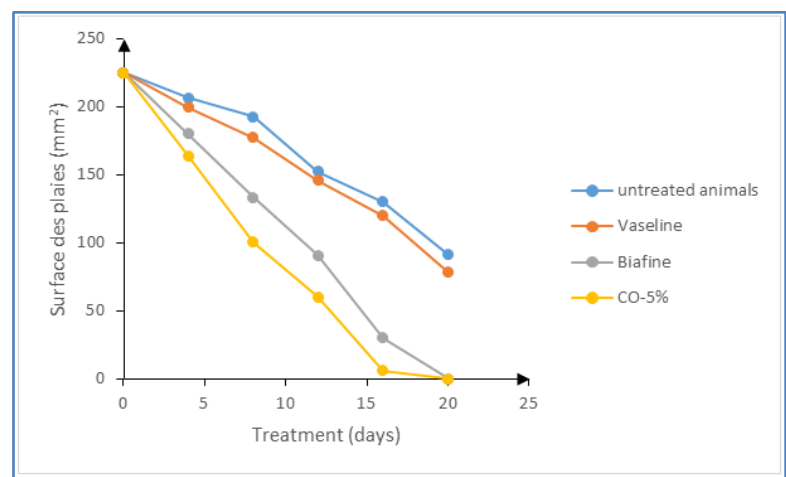

Fig-1: Effect of ointment of Chromoleana odorata extract

\section{DISCUSSION}

Phytochemical screening has highlighted the presence of alkaloids, anthocyanins, anthraquinones, flavonoids, polyphenols, saponins, steroids, tannins and triterpenes in the aqueous extract of Chromoleana odorata leaves. These results are consistent with the work of [12]. The application of the ointment of $\mathrm{C}$. odorata extract showed a better progression and healing of wounds than the batch treated with Biafine, a reference wound healing agent. Research has shown that plants in the Asteraceae family have similar healing and anti-inflammatory properties due to their phytochemical composition [13]. The healing effect is thought to be the effect of alkaloids and tannins that have a hemostatic action by causing localized vasoconstriction to stop the bleeding by forming foam with the blood and reducing blood flow [14]. Lack of infection on wounds treated with $\mathrm{C}$. odorata extract would explain its action in the detertion of wounds, phenolic compounds would precipitate the proteins of the injured tissues by creating a protective layer that isolates the wound from its environment, terpenoids that possess an antimicrobial effect that could be a key factor in healing by inhibiting infection and accelerating the inflammatory process, as well as healing [15-17]. These results provide a rationale for the traditional use of $\mathrm{C}$. odorata in the treatment of wounds.

\section{CONCLUSION}

Chromoleana odorata is used as a widespread remedy in Cameroon to treat wounds. This study assessed the healing effect of an ointment based on this plant. Effect that could be induced by the presence of alkaloids, phenolic compounds and terpenoids highlighted in the water extract. The healing potential of C. odorata is in agreement and justifies its use in the traditional treatment of wounds; hence the importance of this studies in the enhancement of traditional medicine through the production of accessible and effective traditional improved medicines (MTA).

\section{REFERENCES}

1. WHO. (2000). Principes méthodologiques généraux pour la recherche et l'évaluation relatives à la médecine traditionnelle. WHO/EDM/TRM/2000.1.

2. Priya, S. (2010). Place de la médecine traditionnelle dans le système de santé : faits et chiffres. https://www.scidev.net/afrique-subsaharienne/paludisme/article-de-fond/place-de-lam-decine-traditionnelle-dans-le-syst-me-de-santfaits-et-chiffres.html

3. Guedje, M. N., Tadjouteu, F., Dongmo, R. F., Jiofack, B. T., Tsabang, N., Fokunang, C. N., Fotso, S. (2012). Médecne traditionnelle africaine (MTR) et phytomédicaments : défs et strateges de developpement. Health Sciences and Disease, 12 (3).

4. Gautier, L. (1992). Contact forêt-savane en Côte d'Ivoire Centrale : rôle de Chromolaena odorata (L.) R. King et H. Robinson dans la dynamique de la végétation, Thèse $\mathrm{PhD}$, Université de Genève.

5. Koumaglo, K. H., Kokouvi, D., Bettini, F., Bayle, J. C. (2009). Composition chimique de l'huile essentielle de Chromolaena odorata (L) King et Robinson (Asteraceae) du Togo : Effets de séchage et du site de récolte. Journal de la Société Ouest Africaine de Chimie. 028 : 11-16.

6. Pandith, H., Zhang, X., Liggett, J., Min, K. W., Gritsanapan, W., Back, S. J. (2013). Hemostatic and wound healing properties of Chromoleana odorata leaf extract. ISRN Dermatology.

7. Ngono-Ngane, A., Ebelle-Etame, R., Ndifor, F., Biyiti, L., Amvam-Zollo, P. H., Bouchet, P. (2006). Antifungal activity of Chromolaena odorata (L.) King and Robinson (Asteraceae) of Cameroon. Chemotherapy, 52(2): 103-106.

8. Ling, B., Zhang, M., Kong, C., Pang, X., Liang, G. (2003). Chemical composition of volatile oil from Chromolaena odorata and its effect on plant, fungi and insect growth. Ying Yong Sheng Tai Xue Bao, 14(5): 744-746.

9. Harbone, A. J. (1998). Phytochemical methods: A guide to modern techniques of plants analysis. $5^{\text {th }}$ edition, Chapman and Hall, 21-72.

10. Evans, W. C. (2000). Trease and Evans pharmacology, $4^{\text {th }}$ Edition WB Saunders Company Ltd, 224-239.

11. Morton, J.J., Malone M. H. (1972). Evaluation of vulnerary activity by an open wound procedure in rats. Arch Int Pharmacodyn Ther, 196(1): 117-126.

12. N'Guessan, K., Kadja, B., Zirihi, G. N., Traoré, D., Aké-Assi, L. (2009). Screening phytochimique de quelques plantes médicinales ivoiriennes utilisées en pays Krobou (Agboville, Côte-d'Ivoire). Sciences \& Nature. 6(1): 1-15. 
13. Filleul, E. (2018). Les astéracées: description botanique, biologique et étude de plantes médicinales et toxiques. This de Doctorat en Pharmacie, 136.

14. John-Africa, L. B., Aboh, M. (2015). Evaluation of the haemostatic activities of Sida corymbosa in rats. British Journal of Pharmaceutical Research., 5(6): 431-436.

15. Mohtar, M., Shaari, K., Nam, A., Am, A. (1998). Journal of Tropical Forest Products, 4: 199-206.
16. Schulz, V., Hansel, R., Tyler, V. E. (2002). Fitoterapia racional um guia de fitoterapia para ciencias da saude. 4th. Ed. Sao Paulo: Manole, 140.

17. Rosoambolatiana, S. M. (2018). Etude de l'effet de l'extrait DTI4110 sur la cicatrisation des plaies ouvertes chez le rat. Mémoire de Master. Université d'Antanarivo, 42. 